\title{
Human Papilloma Virus-Related Metachronous Tracheal Cancer in a Patient with Tonsillar Cancer
}

\author{
Yun Ji Lee ${ }^{\mathbb{D}}$, Min Ki Lee, Seung Won Lee, and Ki Nam Park \\ Department of Otorhinolaryngology-Head and Neck Surgery, Bucheon Hospital, Soonchunhyang University College of Medicine, \\ Bucheon, Korea
}

편도암 환자에서 발생한 이시성 인간 유두종 바이러스 양성 기관암

이윤지 · 이민기 · 이승원 · 박기남

순천향대학교 의과대학 부천병원 이비인후-두경부외과학교실

\author{
Received March 9, 2020 \\ Revised May 26, 2020 \\ Accepted May 30, 2020 \\ Address for correspondence \\ Ki Nam Park, MD, PhD \\ Department of Otorhinolaryngology- \\ Head and Neck Surgery, \\ Bucheon Hospital, \\ Soonchunhyang University \\ College of Medicine, \\ 170 Jomaru-ro, Bucheon 14584 , \\ Korea \\ Tel +82-32-621-6582 \\ Fax +82-32-621-6950 \\ E-mail man7140@gmail.com
}

Second primary malignancy (SPM) is a well-known cause of death in head and neck cancers. Recently, with reports of many incidences of human papilloma virus (HPV) associated SPM, the disease has been widely investigated. We report a HPV-positive tracheal cancer in a 49 -yearold male who had been diagnosed with HPV-positive squamous cell carcinoma of the right tonsil within intervals of two years. In this case, the metachronous tracheal cancer lesion as well as the primary tonsillar cancer showed the same subtype HPV-16.

Korean J Otorhinolaryngol-Head Neck Surg 2021;64(4):258-62

Key Words Human papilloma virus · Metachronous cancer · Tonsillar cancer · Tracheal cancer.

\section{서 론}

편도는 구인두암이 발생하는 가장 흔한 부위이다. 편도암과 human papilloma virus(HPV)와의 연관성은 잘 알려져 있 으며, HPV는 흡연, 음주와 함께 두경부암의 가장 중요한 원 인이 되는 요인이다. 1990년대 이전에는 구인두 부위가 두경 부암 중 이차성 원발암(second primary malignancy)이 두 번째로 가장 흔하게 발생하는 일차 원발 부위로 알려져 있었 으나, 최근 $\mathrm{HPV}$ 의 출현 이후에는 발생률이 최소 수준으로 현저히 감소했다.1) 두경부암으로 사망하는 환자의 약 $1 / 3$ 은 이차성 원발암에 의한 것이며, 이는 원격 전이로 인한 사망의 약 3 배에 해당한다는 보고가 있는 바,2,3) 두경부 암에서 이차

This is an Open Access article distributed under the terms of the Creative Commons Attribution Non-Commercial License (https://creativecommons.org/licenses/by-nc/4.0) which permits unrestricted non-commercial use, distribution, and reproduction in any medium, provided the original work is properly cited.
성 원발암은 임상적으로 중요하다. 최근, $\mathrm{HPV}$ 와 관련된 이 차성 원발암 증례들이 다수 보고되고 있어, 임상의들과 병리 학자들은 이 질환군에 대해 활발하게 연구 중이다. ${ }^{4)}$ 한편, 기 관암(tracheal cancer)은 100만 명당 1건의 발병률을 보이는 드문 질환이다. ${ }^{5)}$ 본 증례는 고위험 $\mathrm{HPV}$ 양성 편도암 환자에 서, 이시성(metachronous)으로 기관에 이차성 원발암이 발 생한 첫 번째 사례로 문헌 고찰과 함께 보고하는 바이다.

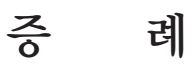

47세 남자 환자가 우측 편도 종물을 주소로 타 병원 내원 하여 시행한 조직 검사에서 편평세포암 소견으로 본원에 의뢰 되었다. 환자는 20갑년 이상의 흡연자였으며 사회적 음주자였 으나 발암 물질에 노출된 과거력은 없었다. 신체 검사에서 우 측 편도에 약 $2 \mathrm{~cm}$ 의 유두상 종물이 확인되었으며(Fig. 1A), 
우측 경부 level II 영역에 약 $3 \mathrm{~cm}$ 의 단단하고 압통이 없으며 주변 조직에 고착된 양상의 종물이 촉지되었다.

경부 컴퓨터단층촬영 검사(neck CT)에서 비대칭적인 편도 의 비대 및 조영 증강 소견을 보였으며, 동측 경부에 다수의 림프절 비대가 확인되었다(Fig. 1B). 가장 큰 림프절은 장경 약 $3 \mathrm{~cm}$ 로 측정되었다. 양전자방출 컴퓨터단층촬영 검사 (PET-CT)에서 동측 림프절 전이를 보였으나, 타 장기 전이의
증거는 없었다(Fig. 1C). 편도 종물의 펀치 생검을 재시행한 결과 중등도 분화도의 편평세포암(moderately differentiated squamous cell carcinoma)(Fig. 1D)이었으며, 함께 시행 한 DNA chip test(Fig. 1E)에서 HPV-16에 대해 양성을 나 타냈다.

환자는 다학제 팀과 논의를 거쳐 6주일 동안 cetuximab을 이용한 항암 및 동시 방사선 치료(concurrent chemoradio-
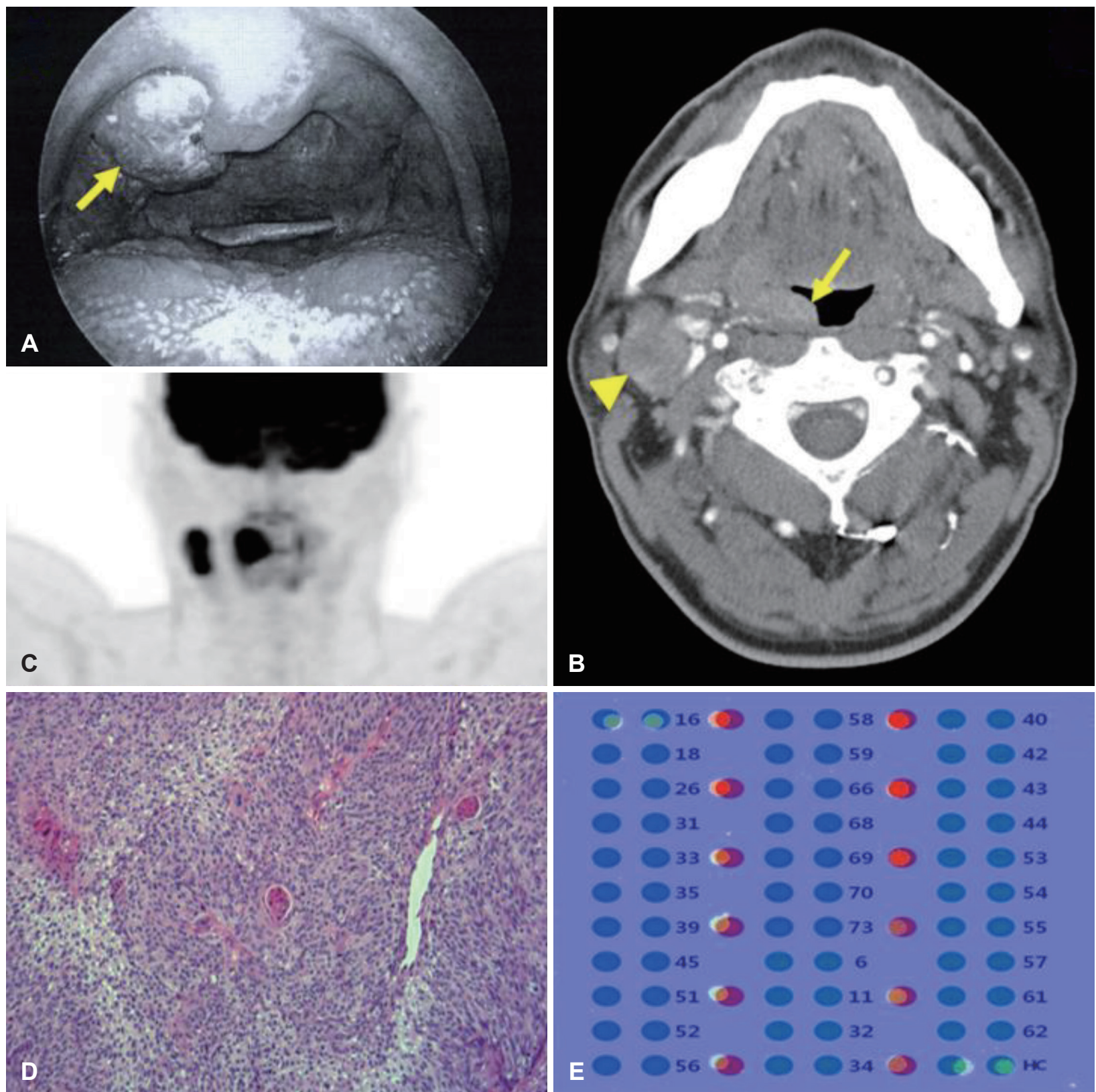

Fig. 1. Initial clinical findings of the patient with right tonsil cancer. A fungating mass was observed at the upper pole of right tonsil on physical examination (arrow) (A). Contrast enhanced neck CT for initial work up shows asymmetrically enlarged right tonsil with increased enhancement (arrow) and multiple heterogeneously enhancing lymph nodes at right neck level II-III, the largest of which is $2 \times 3 \mathrm{~cm}$ (arrowhead) (B). PET-CT shows fluorodeoxyglucose uptake of these lesions suggesting right tonsillar cancer with ipsilateral multiple metastatic lymphadenopathy $(C)$. Hematoxylin and eosin $(\times 100)$ stains from the right tonsil confirmed moderately differentiated squamous cell carcinoma (D). HPV DNA chip test performed at the tonsillar lesion revealed HPV type 16 positive (E). HPV: human papilloma virus. 
therapy, CCRT)(72Gy/40 fractionations)를 시행받았다. CCRT 종료 3개월 후에 시행한 경부 자기 공명 영상 검사(neck MRI) (Fig. 2A)에서 우측 편도의 크기는 감소하였으나, 우측 경부 level II에 일부 림프절이 남아있는 소견을 확인할 수 있었으 며, 이 병변은 PET-CT에서 fluorodeoxyglucose 고섭취를 보이는 전이성 림프절로 판단되었다(Fig. 2B). 우측 측경부의 잔여 림프절에 대해 변형 근치 경부 절제술 type II(Fig. 2C) 및 우측 편도 절제술(Fig. 2D)을 시행하였다. 병리조직학적 결 과에서 총 20 개의 림프절 중 경부 level II의 1 개 림프절에서 편평세포암 전이가 발견되었다. 우측 편도에서는 $1 \times 0.9 \mathrm{~cm}$ 의 고분화 편평세포암(well differentiated squamous cell carcinoma)이 확인되었으며, 심부를 포함하여 모든 절제연에서 종양은 발견되지 않았다.

22개월의 추적 관찰 기간 동안 재발 또는 전이의 증거는 없 었다. 그러나, CT에서 좌측 정중 주위 기관 내강에 약 $1.1 \mathrm{~cm}$ 의 조영 증강되는 병변이 발견되었다(Fig. $3 \mathrm{~A}$ ). 경성 기관지경 검사에서 기관의 내강 내 유두상 종물이 확인되었다(Fig. 3B). 생검 결과 편평세포암이었고, p16 면역염색에 대해 양성, DNA chip test에서 HPV-16 양성이었다(Fig. 3C). 기관암 병변에 대해 3 번째부터 6 번째 기관륜 절제 및 기관 단단문합술과 함 께 갑상선 협부 절제술, 양측 중심 경부 림프절 청소술을 시 행하였고, 기관절개술은 시행하지 않았다(Fig. 3D-F). 수술 중 동결 절편 검사를 시행하여 기관의 절제연에 잔여 종양 세포가 없음을 확인하였다. 수술 2일 후 중환자실에서 기관 내 튜브를 발관하였고, 일반병실로 전실하였다. 병리조직학적 검사 결과 기관에서 점막하층(submucosa)을 침범하는 중분 화도의 편평세포암이 확인되었다. 총 4개의 중심 경부 림프절
에서는 전이 소견을 보이지 않았다. 기관 수술 2주 후 합병증 없이 환자는 퇴원하였다. 환자는 수술 후 4년 8개월의 추적 관찰 기간 동안 편도, 기관 및 경부 등에 재발 및 전이의 소견 없이 외래에서 추적 관찰 중에 있다. 본 연구는 순천향대학교 부천병원 임상연구심의위원회의 승인을 받았다(2019-11-012).

\section{고 찰}

$\mathrm{Warren}^{6}$ 이 제시한 정의에 따르면, 이차성 원발암이란 기 존의 종양과 해부학적으로 구별되는 별개의 부위에서 발생한 종양으로서 조직학적으로 악성으로 증명되고, 전이의 가능성 은 배제되어야 한다고 하였다. 또한 국소 재발과의 감별도 필 요한데, 본 증례에서 편도와 해부학적으로 완전히 분리되어 있는 기관의 점막하층에 국한된 종양이 발생하였고 편도암에 대한 수술 시 기관절개술을 시행하지 않았기 때문에 수술로 인한 종양 파종(seeding)의 가능성은 매우 낮다고 생각되어 임상적으로 이차성 원발암의 정의에 부합한다.

HPV가 두경부암의 중요한 위험인자로 밝혀지면서 이와 관련된 이차성 원발암 또한 새로운 관심사로 부상하였는데, 최근 영국에서 시행한 메타 분석에 따르면 구인두 및 자궁 경부, 외음부 및 항문 등에서 발생한 HPV 양성의 원발암 환 자는 HPV와 관련된 이차성 원발암이 발생할 확률이 약 5 배 증가한다고 하였다. ${ }^{4)}$ 한편, 국내 두경부암 환자 데이터를 분 석한 이시성 이차성 원발암 연구에서는 HPV 양성 구인두암 의 경우 후두, 하인두암보다 이차성 원발암 발생률이 통계적 으로 유의하게 낮게 나타났다.'

기존 연구들에 따르면 이차성 원발암이 호발하는 부위는
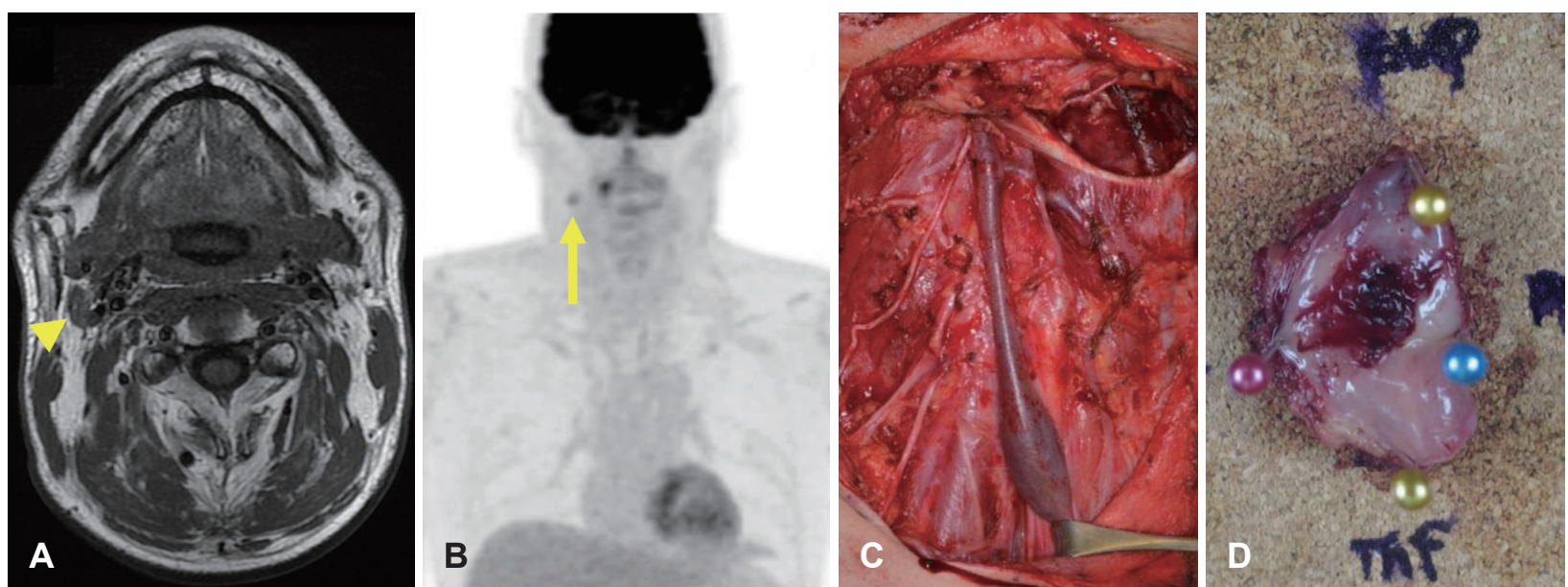

Fig. 2. Recurrence of tonsil cancer and salvage surgery. Three months after concurrent chemoradiotherapy for human papilloma virus positive tonsillar cancer (cT2N2bM0), neck MRI (A) and PET-CT (B) performed. On these examinations, the previous right tonsillar mass was undetected. However, there was a residual metastatic lymph node at the right neck level II (arrowhead and arrow). To remove the remaining lesions completely, a modified radical neck dissection (C) and right wide tonsillectomy (D) performed and the pathologic finding confirmed well differentiated squamous cell carcinoma of right tonsil with metastatic squamous cell carcinoma to one of 20 lymph nodes at the neck level II. 

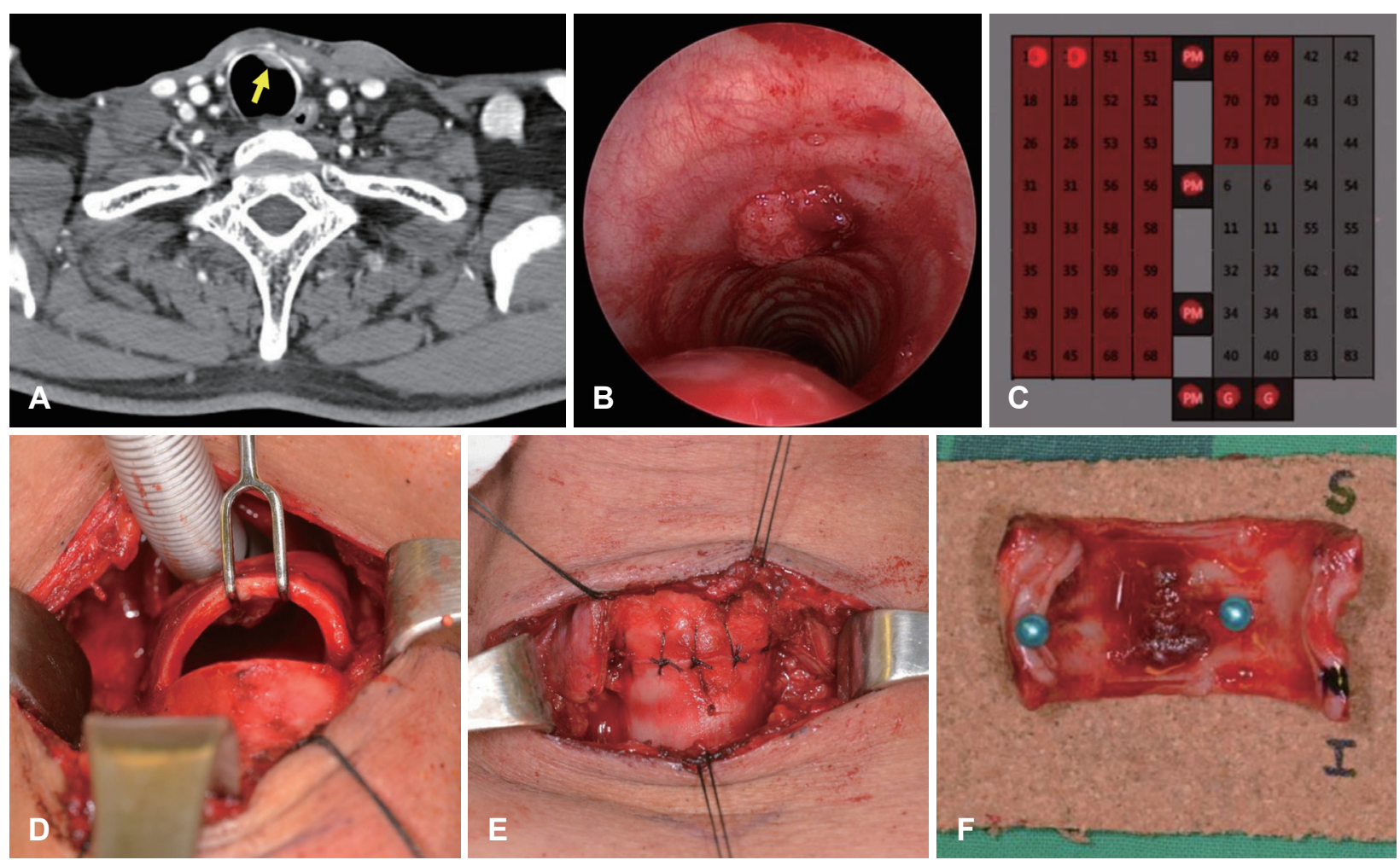

Fig. 3. Diagnosis and treatment for metachronous tracheal cancer. Contrast enhanced neck CT conducted 22 months after surgery showed an approximately $1.1 \mathrm{~cm}$ enhancing nodular lesion in the left anterior tracheal wall (arrow) (A). An endoscopic tracheal mass biopsy performed for pathologic diagnosis and HPV typing (B). The result was squamous cell carcinoma with HPV-16 positive (C). The operative finding shows resected tracheal ring from 3rd to 6th (D). Ten points were sutured to perform tracheal end-to-end anastomosis (E). The specimen showed the papillomatous mass lesion protruding to the tracheal lumen with negative resection margins (F). HPV: human papilloma virus.

두경부, 식도, 폐 등으로 보고되어왔는데, 본 증례에서는 암 발생률 자체가 매우 드문 기관에서 이차성 원발암이 발생하 였으며 이는 문헌상 보고된 바가 없다. 저자들은 환자의 흡연 력과 HPV 감염이 서로 상승적으로 영향을 미친 결과로 예 측한다. Syrjänen ${ }^{8}$ 에 따르면, 원주 세포로 구성되어 있는 호흡 상피는 HPV의 일차 표적이 아니지만, 의인성 편평원주상피 접합부(iatrogenic squamocolumnar junctions) 또는 흡연에 의해 발생한 편평상피화생(squamous metaplasia)은 HPV 감염의 진입 부위가 될 수 있다고 하였다. 즉, 본 증례에서 흡 연에 의해 발생한 기관의 호흡 상피세포의 변화로 인해 HPV 감염에 취약한 환경이 조성되었고 그 결과 이차성 원발암이 기관에서 발생한 것으로 추측한다.

두경부암에서 이차성 원발암이 호발하는 이유는 Slaughter 등 ${ }^{9}$ 이 제시한 상부기식도관(upper aerodigestive tract) 전체가 흡연 등 발암 물질에 동시에 노출되어 발생한다는 ‘field cancerization' 개념이 일반적이다. 그러나 HPV 감염 과 관련된 이차성 원발암이 발생하는 기전에 대해서는 아직 명확히 밝혀지지 않았다. 이를 설명하기 위해서 제시된 가설 에는 단일의 지속적인 HPV 감염이 다초점의 종양을 유발한
다는 것과, $\mathrm{HPV}$ 의 다중 감염이 서로 다른 독립적인 부위에서 발생하여 종양을 유발할 수 있다는 것, 그리고 최초의 HPV 감염에 의해 발생한 클론이 서로 다른 해부학적 부위로 이동 하여 발생하는, 클론이 연관되어 있는 종양을 유발한다는 것 이 있다. ${ }^{10)}$

두경부의 이차성 원발암에서 HPV type을 분석한 이전의 연구들에 따르면, 동일한 HPV-16에 의해 이차성 원발암이 발생하며, 일부에서는 염기 서열이 완전히 일치하는 결과를 보였다고 보고하였다. ${ }^{11,12)}$ 한편 여성의 경우 HPV 양성 구인두 암을 진단받은 환자군에서 이차성 자궁경부암 발병률이 유 의하게 높다고 하였으며, 자궁경부는 잘 알려진 $\mathrm{HPV}$ 연관 암 호발 부위이다. 이러한 가설 및 연구 결과들을 토대로, 일 차적으로 발생한 종양에서 $\mathrm{HPV}$ 감염이 존재하는 경우 시간 간격을 두고 별개의 해부학적 부위, 특히 HPV 감염이 쉽게 발생하는 위치에 이차성 원발암을 발생시키는 위험 요인으로 서 작용함을 추정할 수 있겠다.

두경부의 국소 진행성 편평세포암(locoregionally advanced squamous cell carcinoma)에서 cetuximab을 사용하는 CCRT 는 치료 효과가 입증되어 널리 사용되고 있다. ${ }^{13)}$ 그러나 항암 
치료나 방사선치료 자체가 이차성 원발암의 위험요인으로 작 용할 수 있어 이에 대한 많은 연구가 시행되어왔다. 최근 시 행된 임상 시험에 따르면(RTOG 0234) 두경부 국소 진행성 편평세포암 환자들을 대상으로 수술 및 cisplatin과 cetux$\mathrm{imab}$ 병합 요법을 시행한 군의 약 $8 \%$ 에서 이차성 원발암이 발생하였다고 보고한 바 있으나, ${ }^{14)}$ 이는 기존에 두경부암에서 이차성 원발암 발생률이 약 8 20\% 정도로 보고되었던 것과 유사한 결과이다. ${ }^{2,15)}$ 아직까지 구인두암을 포함한 두경부 종 양에서 항암치료가 이차성 원발암에 미치는 영향력에 대해 서 밝혀진 바는 제한적이다. 따라서 초치료로 수술을 선택한 경우와 CCRT를 시행한 경우, CCRT가 이차성 원발암 발생 및 생존률에 미치는 위험 영향에 대해서는 보다 많은 연구가 필요할 것으로 생각된다. 특히 HPV status를 포함한 biomarker 또한 이차성 원발암 발생의 중요 위험 요인으로 예상 되는 바, 이를 포함한 다각적 위험 요인 분석을 통해 임상적 으로 치료 방법 적용에 반영할 수 있을 것으로 기대된다.

임상의들은 일차 암 진단 시 HPV 감염이 확인된 환자의 경우 이차성 원발암을 일으키는 독립 위험 요인으로 작용할 수 있으므로 HPV 관련 이차성 원발암이 다양한 해부학적 위치에서 발생할 수 있음을 주지하여 추적 관찰 시 적절한 검사들을 선택하여 시행하여야 할 것이다. 또한 $\mathrm{HPV}$ 양성 종양 및 이차성 원발암의 발생 기전에 대한 연구를 통해 이 질환에 특이적인 치료법 개발 또한 가능할 것으로 생각된다.

\section{Acknowledgments}

This work was supported by Soonchunhyang University Research Fund.

\section{Author Contribution}

Conceptualization: Ki Nam Park. Data curation: Ki Nam Park, Yun Ji Lee. Formal analysis: Ki Nam Park. Investigation: Yun Ji Lee, Min Ki Lee. Methodology: Ki Nam Park. Project administration: Ki Nam Park, Yun Ji Lee. Resources: Ki Nam Park. Supervision: Seung Won Lee, Ki Nam Park. Validation: Ki Nam Park. Visualization: Yun Ji Lee, Min Ki Lee. Writing_original draft: Ki Nam Park, Yun Ji Lee. Writing — review \& editing: Ki Nam Park, Yun Ji Lee.

\section{ORCIDs}

Ki Nam Park https://orcid.org/0000-0001-6641-3981

Yun Ji Lee https://orcid.org/0000-0002-6238-1801

\section{REFERENCES}

1) Morris LG, Sikora AG, Patel SG, Hayes RB, Ganly I. Second primary cancers after an index head and neck cancer: Subsitespecific trends in the era of human papillomavirus-associated oropharyngeal cancer. J Clin Oncol 2011;29(6):739-46.

2) León X, Quer M, Diez S, Orús C, López-Pousa A, Burgués J. Second neoplasm in patients with head and neck cancer. Head Neck 1999;21(3):204-10.

3) Garavello W, Ciardo A, Spreafico R, Gaini RM. Risk factors for distant metastases in head and neck squamous cell carcinoma. Arch Otolaryngol Head Neck Surg 2006;132(7):762-6.

4) Gilbert DC, Wakeham K, Langley RE, Vale CL. Increased risk of second cancers at sites associated with HPV after a prior HPVassociated malignancy, a systematic review and meta-analysis. Br J Cancer 2019;120(2):256-68.

5) Wu CC, Shepard JA. Tracheal and airway neoplasms. Semin Roentgenol 2013;48(4):354-64.

6) Warren S. Multiple primary malignant tumors. A survey of the literature and a statistical study. Am J Cancer 1932;16:1358-414.

7) Jung YS, Lim J, Jung KW, Ryu J, Won YJ. Metachronous second primary malignancies after head and neck cancer in a Korean cohort (1993-2010). PLoS One 2015;10(7):e0134160.

8) Syrjänen KJ. HPV infections and lung cancer. J Clin Pathol 2002; 55(12):885-91.

9) Slaughter DP, Southwick HW, Smejkal W. Field cancerization in oral stratified squamous epithelium; clinical implications of multicentric origin. Cancer 1953;6(5):963-8.

10) McGovern SL, Williams MD, Weber RS, Sabichi A, Chambers MS, Martin JW, et al. Three synchronous HPV-associated squamous cell carcinomas of Waldeyer's ring: Case report and comparison with Slaughter's model of field cancerization. Head Neck 2010; 32(8):1118-24.

11) Caley A, Evans M, Powell N, Paleri V, Tomkinson A, Urbano TG, et al. Multicentric human papillomavirus-associated head and neck squamous cell carcinoma. Head Neck 2015;37(2):202-8.

12) Joseph AW, Ogawa T, Bishop JA, Lyford-Pike S, Chang $X$, Phelps $\mathrm{TH}$, et al. Molecular etiology of second primary tumors in contralateral tonsils of human papillomavirus-associated index tonsillar carcinomas. Oral Oncol 2013;49(3):244-8.

13) Bonner JA, Harari PM, Giralt J, Cohen RB, Jones CU, Sur RK, et al. Radiotherapy plus cetuximab for locoregionally advanced head and neck cancer: 5 -year survival data from a phase 3 randomised trial, and relation between cetuximab-induced rash and survival. Lancet Oncol 2010;11(1):21-8.

14) Harari PM, Harris J, Kies MS, Myers JN, Jordan RC, Gillison ML, et al. Postoperative chemoradiotherapy and cetuximab for highrisk squamous cell carcinoma of the head and neck: Radiation Therapy Oncology Group RTOG-0234. J Clin Oncol 2014;32(23): 2486-95.

15) Erkal HS, Mendenhall WM, Amdur RJ, Villaret DB, Stringer SP. Synchronous and metachronous squamous cell carcinomas of the head and neck mucosal sites. J Clin Oncol 2001;19(5):1358-62. 